\title{
Pemeriksaan Keuangan Negara pada Masa Pandemi COVID-19
}

\section{Glory Augusta E.M. Sianipar ${ }^{1}$; Lilis Ardini}

1) Sekolah Tinggi IImu Ekonomi Indonesia (STIESIA) Surabaya, email: gloryaugusta@gmail.com

2) Sekolah Tinggi IImu Ekonomi Indonesia (STIESIA) Surabaya, email: lilisardini@stiesia.ac.id

\section{ARTICLES INFORMATION}

ABSTRACT

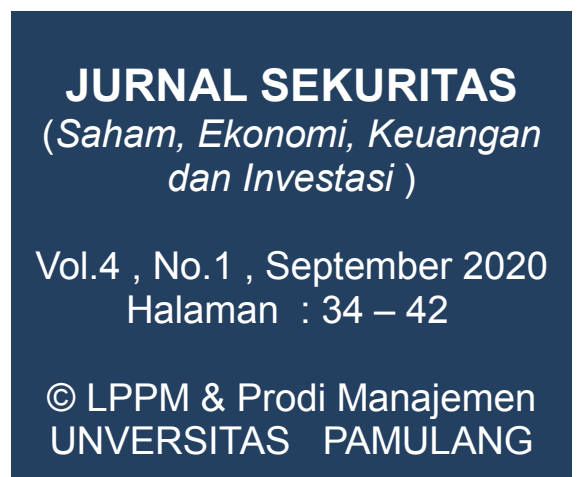

\section{ISSN (online) : 2581-2777 ISSN (print) : 2581-2696}

\section{Keyword :}

Audit; Keuangan Negara;

Covid-19; Kebijakan Keuangan

JEL. classification :

C33, G21, G24, N15, N25

\section{Contact Author :}

PRODI MANAJEMEN UNPAM

JL.Surya Kencana No.1

Pamulang Tangerang Selatan Banten

Telp. (021) 7412566, Fax (021) 7412491 Email :

sekuritas@unpam.ac.id
Penelitian ini bertujuan untuk mengetahui bagaimana strategi dan kebijakan pemeriksaan yang akan dilakukan BPK RI menghadapi banyaknya relaksasi kebijakan dalam keuangan akibat Pandemi COVID-19. Berbagai macam regulasi telah diterbitkan pemerintah akibatnya timbul risiko-risiko rendahnya pengawasan, buruknya akuntabilitas dan penyalahgunaan wewenang yang mengarah ke tindak korupsi. Penelitian ini berdasarkan studi literatur. Metode pengumpulan data dengan dokumentasi. Dari pembahasan menunjukkan sejumlah strategi dan kebijakan yang telah dipersiapkan BPK RI secara comprehensive dengan penilaian berbasis risiko.

This study aimed to determine how the auditing strategy and policy that will be carried out by BPK RI facing many relaxation policies in finance due to the COVID-19 Pandemic. Many regulations have been issued by the government caused risks such as of low supervision, poor accountability and abuse of authority that leads to acts of corruption. Data collection method is documentation. The discussion shows a number of strategies and policies that have been prepared by BPK RI comprehensively with risk-based assessment. 


\section{A. PENDAHULUAN}

Wabah virus Covid 19 (SARS CoV-2) adalah jenis virus baru yang menginfeksi seluruh neçara di dipnia. Gejala umum yang dialami orang terinfeksi virus ini yaitu demam, pilek, batuk kering, sesak, dan kesulitan bernapas. Virus ini berasal dari kota Wuhan, Cina yang diperkirakan ditularkan melalui hewan ke manusia, virusnya menyebar dengan cepat hingga mencapai Indonesia. Status darurat bencana pandemi virus ditetapkan mulai tanggal 29 Februari 2020 hingga 29 Mei 2020 oleh Pemerintah Indonesia. Virus ini telah menyebar dengan cepat ke seluruh Indonesia diketahui bahwa 28 Juni 2020 warga negara Indoneisa yang positif Covid-19 berjumlah 54.010 dengan angka pasien yang meninggal dunia sebanyak 2.754 orang dan angka total kesembuhan mencapai 22.936. WHO dan pemerintah mengeluarkan kebijakan untuk sementara waktu menghentikan semua kegiatan di luar rumah seperti bekerja dan sekolah (Fajrian, 2020).

Dalam upaya menghadapi penyebaran virus di Indonesia pemerintah mengeluarkan berbagai peraturan perundang-undangan. Pakpahan (2020) menyatakan pemerintah mengeluarkan kebijakan jangka pendek dan jangka panjang bagi UMKM. Bantuan keuangan jangka pendek yang diberikan pemerintah berupa bantuan tunai langsung atau pinjaman lunak dan penggunaan teknologi digital dapat digunakan sebagai strategi jangka panjang. Selain itu, Hanoatubun (2020) menyatakan dalam upaya mengembangkan perekonomian pemerintah Indonesia menurunkan Bank Indonesia 7day Reverse Repo Rate (BI7DRR) menjadi 4,75\%, suku bunga Lending Facility menjadi $5,50 \%$ dan suku bunga Deposit Facility menjadi 4,40\% sebagai upaya untuk menjaga pertumbuhan ekonomi domestik dan permulihan ekonomi global di masa pandemi Covid19.

Pemerintah juga mengeluarkan kebijakan-kebijakan dalam rangka mempercepat penggunaan untuk mengelola Anggaran Pendapatan dan Belanja Negara (APBN) dan Anggaran Pendapatan dan Belanja Daerah (APBD) untuk mengantisipasi dan mengelola efek Covid-19 serta pertanggungjawabannya. Presiden memberikan instruksi kepada pemerintah daerah yang mengambil kebijakan Pembatasan Sosial Berskala Besar (PSBB) untuk memperhatikan dampak ekonomi yang disebabkan oleh kebijakan itu dan memberikan bantuan sosial kepada masyarakat yang terkena dampak. Presiden menetapkan Perppu Nomor 1 tahun 2020 yang mengatur tentang kebijakan keuangan dan stabilitas sistem keuangan negara dan daerah (Pemerintah Republik Indonesia, 2019).

Tidak ada pemerintah pusat maupun daerah yang siap menghadapi peristiwa pandemi Covid-19. Oleh karena itu, pemerintah memberikan sejumlah relaksasi kebijakan dalam penanganan Covid-19 dari penganggaran, pengadaan barang dan jasa, penyaluran dan penggunaan $\mathrm{DBH}$, DAU, dan Dana Insentif Daerah serta penyaluran Dana Alokasi Khusus Fisik Bidang Kesehatan dan Dana Bantuan Operasional Kesehatan Dalam Rangka Pencegahan dan/atau Penanganan Corona Virus Disease 2019 (Dan et al., 2020). Menurut Sujai (2012) dalam penelitiannya menyatakan bahwa percepatan realisasi anggaran dapat dilakukan dengan menyederhanakan mekanisme pengadaan (procurement) dan mekanisme administrasi anggaran agar prosedurnya lebih mudah dan prosesnya lebih cepat.

Banyaknya kebijakan relaksasi dalam penganggaran, realisasi dan pertanggungjawaban pada Pemerintah Daerah menimbulkan kekhawatiran terkait akuntabilitas pemerintah daerah. Seperti dana bantuan sosial dapat membuka celah bagi seseorang atau beberapa kelompok untuk melakukan tindakan korupsi, karena dalam situasi bencana mengakibatkan pengawasan dan transparansi menjadi lemah terhadap distribusi dana ini. Tindakan korupsi yang biasa dilakukan seperti mengurangi alokasi dana yang disalurkan, atau tidak menyalurkan dana sama sekali, atau bisa juga dengan menyalurkan dana ke penerima fiktif. 
Untuk mendukung keberhasilan pelaksanaan pengelolaan keuangan sektor publik, pengelolaan dikelola secara tertib, efisien, efektif, ekonomis, transparan dan bertanggungjawab serta mematuhi hukum dan peraturan dengan tetap memperhatikan rasa keadilan dan kepatuhan (Bastian, 2010).

\section{B. KAJIAN LITERATUR}

\section{Agency Problem}

Kepentingan yang tidak selaras diantara prinsipal dan agen menyebabkan munculnya agency theory. Menurut Jensen dan Meckling (1976) setiap individu memiliki kepentingan sendiri dan termotivasi untuk mencapainya sehingga menimbulkan konflik diantara prinsipal dan agen. Agency problem dapat terjadi di sektor privat dan publik. Pada sektor privat, agency problem terjadi antara manajemen dengan pemegang saham sedangkan pada sektor publik agency problem terjadi antara politisi dengan rakyat (Zimmerman, 1977). Transparansi penggunan anggaran negara dibutuhkan oleh rakyat untuk memastikan bahwa kesejahteraan telah terpenuhi sedangkan politisi memiliki kepentingan dipilih kembali sehingga dapat memanfaatkan anggaran negara untuk kepentingan kelompok/individunya. Untuk itu, laporan keuangan perlu diaudit oleh pihak independen untuk mengurangi asimetri informasi anatara politisi dan rakyat (Setyaningrum, 2012).

\section{Pemeriksaan Laporan Keuangan Pemerintah}

Undang-undang Nomor 15 Tahun 2004 menjelaskan bahwa pemeriksaan merupakan proses mengidentifikasi masalah, menganalisis dan mengevaluasi berdasarkan standar pemeriksaan yang dilakukan secara independen, objektif dan profesional untuk menilai kebenaran, kecermatan, kredibilitas dan keandalan infomasi terkait pengelolaan dan tanggung jawab keuangan negara (Indonesia, 2004).

Pemeriksaan Keuangan Negara meliputi pengelolaan dan tanggungjawab keuangan negara yang dilakukan oleh Badan Pemeriksa Keuangan (BPK). Peraturan tersebut merupakan dasar Badan Pemeriksa Keuangan untuk melaksanakan 3 (tiga) jenis pemeriksaan yaitu: pemeriksaan keuangan, pemeriksaan kinerja dan pemeriksaan dengan tujuan tertentu (Badan Pemeriksa Keuangan Republik Indonesia, 2008). Hasil pemeriksaan BPK selain memberikan opini juga memberikan catatan hasil temuan pemeriksaan. Temuan pemeriksaan menjelaskan kelemahan dalam sistem pengendalian internal dan ketidakpatuhan terhadap peraturan perundang-undangan. Selain itu, hasil audit memberikan informasi mengenai adanya potensi kerugian negara yang diakibatkan penyalahgunaan dan inefisiensi penggunaan APBN/APBD. Hasil audit BPK tersebut dapat ditindaklanjuti menjadi audit investigasi dan kasus korupsi serta kasus pidana.

Laporan Keuangan Pemerintah merupakan pertanggungjawaban pemerintah pusat dan daerah atas pelaksanaan anggaran belanja negara sebagaimana diatur dalam peraturan perundang-undangan. Berdasarkan PP No.8 tahun 2006 tentang pelaporan keuangan dan kinerja instansi pemerintah, pemerintah harus menyusun laporan keuangan yang meliputi laporan realisasi anggaran, neraca, laporan arus kas, catatan atas laporan keuangan (Indonesia, 2006).

Tujuan laporan keuangan pemerintah pusat dan daerah diaudit yaitu untuk memastikan bahwa LK telah disusun secara wajar dan telah sesuai dengan standar akuntansi pemerintahan. 


\section{Kebijakan Pemerintah terkait Keuangan dalam Masa Pandemi COVID-19}

Sejumlah Regulasi yang dikeluarkan terkait Pengelolaan Keuangan Negara dan Daerah dalam masa pandemi COVID-19 diantaranya:

1. Perppu Nomor 1 Tahun 2020 tentang Kebijakan Keuangan Negara dan Stabilitas Sistem Keuangan untuk Penanganan Pandemi Covid-19 dan/atau Dalam Rangka Menghadapi Ancaman yang Membahayakan Perekonomian Nasional dan/atau Stabilitas Ekonomi (Pemerintah Republik Indonesia, 2019);

2. Perpres Nomor 16 Tahun 2018 tentang Pengadaan Barang/Jasa Pemerintah pada Bab VIII Pengadaan Khusus mengatur pengadaan dalam keadaan darurat (Presiden et al., 2020);

3. Inpres Nomor 4 Th. 2020 Tgl 20 Maret 2020 tentang Refocussing Kegiatan, Realokasi Anggaran, serta PBJ dalam rangka Percepatan Penanganan Covid-19 (Presiden et al., 2020);

4. Permenkeu Nomor 19/PMK.07/2020 tanggal 16 Maret 2020 tentang Penyaluran dan Penggunaan DBH, DAU, dan Dana Insentif Daerah TA 2020 Dalam Rangka Penanggulangan Corona Virus Disease 2019 (Kementerian Keuangan RI, 2020);

5. Keputusan Menkeu Nomor 6/KM.7/2020 tanggal 14 Maret 2020 tentang Penyaluran Dana Alokasi Khusus Fisik Bidang Kesehatan dan Dana Bantuan Operasional Kesehatan Dalam Rangka Pencegahan dan/atau Penanganan Corona Virus Disease 2019 (Kementerian Keuangan RI, 2020);

6. Keputusan Bersama Mendagri dan Menkeu Nomor 119/2813/SJ dan Nomor 177/KMK.07/2020 tentang Percepatan Penyesuaian APBD Tahun 2020 Dalam Rangka Penanganan Covid-19 serta Pengamanan Daya Beli Masyarakat dan Perekonomian Nasional;

7. Peraturan Menteri Dalam Negeri No.39 tahun 2020 tentang Pengutamaan Penggunaan Alokasi Anggaran untuk kegiatan tertentu, Perubahan Alokasi dan Penggunaan Anggaran Pendapatan dan Belanja Daerah (Kementerian Dalam Negeri RI, 2020);

8. Keputusan Menkes HK.01.07/MENKES/238/2020 tgl 6 Apr 2020 tentang Petunjuk Teknis Klaim Penggantian Biaya Perawatan Pasien Penyakit Infeksi Emerging Tertentu Bagi Rumah Sakit Yang Menyelenggarakan Pelayanan Covid-19 (Kementerian Kesehatan RI, 2020);

9. SE Menkes Nomor HK.02.01/MEN KES/295/2020tgl 24 Apr 2020 tentang Klaim Penggantian Biaya Perawatan Pasien Penyakit Infeksi Emerging Tertentu Bagi Rumah Sakit yang Menyelenggarakan Pelayanan Covid-19 (SE No. HK.02.01-MENKES-2952020 Tentang Klaim Penggantian Biaya Perawatan.Pdf, n.d.);

10. SE KPK No.11 Tahun 2020 tentang Penggunaan Data Terpadu Kesehatan Sosial (DTKS) dan Non DTKS dalam Pemberian Bantuan Sosial Ke Masyarakat (SE-11-2020Tentang-Penggunaan-Kesejahteraan-Sosial-DTKS-Dan-Data-Non-DTKS-DalamPemberian-Bantuan-Sosial-Ke-Masyarakat.Pdf, n.d.).

\section{Kebijakan dan Strategi Pemeriksaan oleh BPK}

Dalam masa darurat Covid-19 Badan Pemeriksa Keuangan (BPK) mengambil sejumlah langkah sebagai respons atas kebijakan pencegahan penyebaran wabah virus Corona atau Covid-19. BPK memastikan proses audit Laporan Keuangan Pemerintah Pusat (LKPP) dan Laporan Keuangan Pemerintah Daerah (LKPD) tetap berjalan meskipun masih ada pandemi Covid-19. Untuk tetap menjaga kualitas pemeriksaan laporan keuangan tahun anggaran 2019 sesuai dengan Standar Pemeriksaan Keuangan Negara (SPKN), BPK melakukan pemeriksaan dengan Panduan Pemeriksaan Keuangan pada Masa Darurat Covid-19.

Untuk menghadapi LK tahun anggaran 2020 BPK melakukan pemeriksaan secara menyeluruh (comprehensive) melalui tiga jenis pemeriksaan yaitu keuangan, kinerja dan 
dengan tujuan tertentu sesuai Undang-undang No.15 tahun 2004 tentang Pemeriksaan Pengelolaan dan Tanggungjawab Keuangan Negara. Melalui tiga jenis pemeriksan tersebut BPK melakukan pemeriksaan keuangan negara yang memberikan nilai tambah, pada saat atau pasca penanganan pandemi.

1. Pemeriksaan Keuangan

BPK memberikan perhatian pada pergeseran anggaran APBN dan APBD tahun 2020 yang dialokasikan untuk penanganan Covid-19.

2. Pemeriksaan Kinerja

Pemeriksaan kinerja dilakukan terhadap program/kegiatan penanganan pandemi yang dilakukan oleh pemerintah, bertujuan untuk menilai efektivitas program.

3. Pemeriksaan dengan Tujuan Tertentu

Pemeriksaan dengan tujuan tertentu (PDTT) berfokus pada kepatuhan dan pengendalian internal dalam penggunaan keuangan negara untuk menangani Covid19 , termasuk pemeriksaan investigasi.

\section{METODOLOGI PENELITIAN}

Pendekatan yang digunakan dalam penelitian ini adalah studi literatur terkait pemeriksaan keuangan negara terkait masalah-masalah keuangan efek dari pandemi Covid-19 dan kebijakan-kebijakan yang diterbitkan pemerintah untuk relaksasi. Dalam penelitian ini peneliti menggunakan studi literatur dimana peneliti mengambil berbagai sumber referensi yang mendukung penelitian ini. Teknik pengambilan data penelitian ini akan dilakukan dalam dua langkah. Langkah pertama yaitu melakukan studi literatur pada buku, jurnal, peraturan dan webinar yang berhubungan dengan pengelolaan dan kebijakan keuangan negara di masa pandemi Covid-19. Langkah kedua yaitu dilakukan analisis atas data sekunder yang diperoleh. Terhadap data-data tersebut akan dikompilasi, dianalisis dan disimpulkan sehingga diperoleh kesimpulan mengenai studi literatur.

\section{HASIL DAN PEMBAHASAN}

Pemeriksaan yang dilakukan oleh BPK merupakan pemeriksaan berbasis risiko secara menyeluruh (comprehensive) melalui tiga jenis pemeriksaan yaitu keuangan, kinerja dan dengan tujuan tertentu terhadap pengelolaan dan tanggungjawab keuangan negara dalam penanganan pademi Covid-19. Ruang lingkup pemeriksaan BPK meliputi refocusing dan realokasi anggaran untuk penanganan Covid-19 serta tambahan belanja negara/daerah serta skema program permulihan ekonomi nasional (PEN).

Table 1. Cakupan Pemeriksaan

\begin{tabular}{clc}
\hline No. & \multicolumn{1}{c}{ Cakupan Pemeriksaan } & Nilai \\
\hline 1 & APBN Refocusing & Rp 190 Triliun \\
2 & APBN Realokasi & Rp 54,6 Triliun \\
3 & APBD Penanganan COVID-19 & Rp 67,21 Triliun \\
4 & Tambahan Belanja dan PEN & Rp 695,2 Triliun \\
5 & Pelebaran Defisit & $6,34 \%$ dari PDB \\
\hline \multicolumn{2}{c}{ Sumber: Badan Pemeriksa Keuangan (2020) }
\end{tabular}

\section{Strategi Pemeriksaan BPK RI}

Strategi pemeriksaan BPK dalam pengelolaan dan tanggungjawab keuangan negara dalam penanganan pademi Covid-19 sebagai berikut:

1. Renstra BPK

Strategi pemeriksaan BPK ditetapkan dalam kebijakan pemeriksaan yang tertuang dalam rencana strategis BPK. 
2. Prioritas

BPK akan melaksanakan pemeriksaan terhadap program prioritas pemerintah dalam penanganan Covid-19.

3. Sumber Daya

Menggunakan sumber daya yang dimiliki antara lain SDM, keuangan, sarpras, serta standar/sistem/pedoman pemeriksaan yang sudah dikembangkan dan ditetapkan

4. Pedoman

BPK juga menetapkan pedoman pelaksanaan pemeriksaan dalam situasi Covid19 atau keadaan bencana (ISSAI 5500)

5. Teknologi Informasi

Pelaksanaan pemeriksaan BPK dilakukan dengan optimalisasi pemanfaatan teknologi informasi seperti Teknik Audit Berbantuan Komputer (TABK), Big Data Analytic.

\section{Prosedur Pemeriksaan pada Masa Darurat COVID-19}

Pemeriksaan yang dilakukan BPK tetap mematuhi standar yang telah dipersyaratkan Standar Pemeriksaan Keuangan Negara (SPKN), Standar Profesional Akuntan Publik (SPAP), Standar Akuntansi Pemerintahan (SAP), Panduan Manajemen Pemeriksaan (PMP) dan Juknis pemeriksaan keuangan berlaku.

Panduan Pemeriksaan termasuk prosedur alternatif dalam masa darurat bencana disusun untuk melengkapi Petunjuk Pelaksanaan (Juklak) dan Petunjuk Teknis (Juknis) pemeriksaan yang ada di BPK. Panduan Pemeriksaan LKPD merupakan pengembangan atas kebijakan umum pemeriksaan LKPD dengan mengadopsi sumbersumber literatur yang relevan dengan kondisi pemeriksaan Laporan Keuangan Pemerintah (Badan Pemeriksa Keuangan Republik Indonesia, 2020). Dalam keadaan luar biasa masa pandemi Covid-19 pelaksanaan pemeriksaan tetap berdasarkan Standar Pemeriksaan Keuangan Negara (SPKN) dan melaksanakan prosedur alternatif dengan mengoptimalisasi penggunaan teknologi informasi dan komunikasi untuk menghindari terjadinya kontak fisik.

\section{Ruang Lingkup Audit dalam Kondisi Darurat}

Berdasarkan kebijakan yang telah dikeluarkan baik oleh pemerintah pusat maupun pemerintah daerah dalam masa relaksasi kebijakan euangan akibat Pandemi Covid-19. BPK melakukan mapping lingkup keuangan negara yang memiliki risiko karena adanya regulasi-regulasi baru yang diterapkan dalam kondisi darurat. Mapping yang dilakukan BPK bertujuan untuk mempermudah penentuan objek audit dengan penilaian risiko. 
Gambar 1. Audit Mapping

\begin{tabular}{|c|c|c|c|c|c|c|}
\hline \multicolumn{7}{|c|}{ Kerangka Regulasiddalam Kondisi Darurat } \\
\hline Keuangan Negara & APBN & $A P B D$ & Dana BI & Dana LS & Dana BUMW & Dana Masyarakat \\
\hline Sektor & 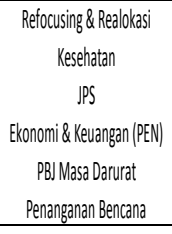 & $\begin{array}{c}\text { Refocusing \& Realokasi } \\
\text { Kesehatan } \\
\text { JPS } \\
\text { Ekonomi \& Keuangan (PEN) } \\
\text { Penanganan Bencana }\end{array}$ & Kevangan & Kevangan & BUMN & Masyarakat \\
\hline Sumber Anggaran & $\begin{array}{l}\text { Refocusing \& Realokasi } \\
\text { Penghematan Belanjia } \\
\text { Realokssi Cadangan } \\
\text { Penghemattan TKDD } \\
\end{array}$ & $\begin{array}{c}\text { TKDD } \\
\text { Refocusing \& Realokasi }\end{array}$ & Anggaran Tahunan Bl & $\begin{array}{c}\text { Modal Awal } \\
\text { Kontribusi Keppesertaan } \\
\text { Premi Penjaminan } \\
\text { Hasil Investasi Cadannanan Penjaminan }\end{array}$ & Anggaran BUMN & $\begin{array}{l}\text { Hibah Dalam Negeri } \\
\text { Hibah Luar Negeri } \\
\text { Donasi }\end{array}$ \\
\hline Pengangeran & \begin{tabular}{|c|} 
Refocusing \& Reablokasi \\
Kesehatan \\
JPS \\
Ekonomi\& Keuangan (PEN) \\
PBJ Mass Darurat \\
Penanganan Bencana \\
\end{tabular} & $\begin{array}{l}\text { Refocousing \& Realokasi } \\
\text { Kesehatan } \\
\text { JPS } \\
\text { Ekonomi \& Keunngan (PEN) } \\
\text { Penanganan Bencana }\end{array}$ & 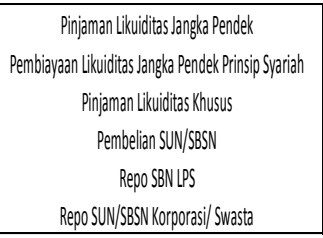 & Penjaminan Simpanan Kelompok Nasababa & CSR & $\begin{array}{c}\text { Pembelian Barang } \\
\text { Santunan } \\
\text { Hibah dari Donatur ke Penerima }\end{array}$ \\
\hline Monev dan Pengawesan & $\begin{array}{c}\text { BPKP } \\
\text { Inspektorortlenderal K/L }\end{array}$ & $\begin{array}{c}\text { Kemdaggi } \\
\text { Inspeltorat Daerah } \\
\end{array}$ & Departemen Audit hternal & Audit lnternal & Audit internal & BNPB \\
\hline Pelaporan dan Pertangusungjawaban & $\begin{array}{l}\text { LKPP/LKKL/LKBUN } \\
\text { Laporan Interim } \\
\text { Laporan Manjajemen }\end{array}$ & $\begin{array}{c}\text { LPKD } \\
\text { Laporan Interim } \\
\text { Laporan Manajemen } \\
\end{array}$ & $\begin{array}{c}\text { LKT BI } \\
\text { Laporan Interim } \\
\text { Laporan Manajemen } \\
\end{array}$ & $\begin{array}{c}\text { LKLPS } \\
\text { Laporan Interim } \\
\text { Laporan Manajemen } \\
\end{array}$ & $\begin{array}{c}\text { LKBUUNN } \\
\text { Laporan Interim } \\
\text { Laporan Manajemen } \\
\end{array}$ & $\begin{array}{l}\text { LPJ Dana Masyarakat } \\
\text { Laporan Interim } \\
\text { Laporan Manajemen }\end{array}$ \\
\hline \multicolumn{7}{|c|}{ Pemangku Kebjijkan (Kemenko, Kementerian Keuangan, KLL, KSSK, B, OUK, LPS) } \\
\hline \multicolumn{7}{|c|}{ Pelaksana Kebjiakan } \\
\hline & & & Penerima Manfaat & & & \\
\hline
\end{tabular}

Sumber: Badan Pemeriksa Keuangan (2020)

\section{E. KESIMPULAN}

Kesimpulan yang didapatkan dalam penelitian ini yaitu dengan adanya kebijakankebijakan terkait keuangan negara dalam masa pandemi COVID-19 menimbulkan kekhawatiran terkait akuntabilitas pemerintah daerah. Risiko-risiko dapat menyebabkan terjadinya tindakan korupsi, karena dalam situasi bencana mengakibatkan pengawasan dan transparansi menjadi lemah. Untuk itu, BPK melakukan mitigasi risiko dalam pengelolaaan keuangan negara dalam penanganan COVID-19. Dengan melakukan mitigasi risiko dan menentukan objek audit yang tepat BPK dapat menyelenggarakan pemeriksaan pengelolaan dan tanggung jawab keuangan negara tepat sasaran. 


\section{DAFTAR PUSTAKA}

Badan Pemeriksa Keuangan Republik Indonesia. (2008). Buku Petunjuk Pelaksanaan Pemeriksaan Keuangan. 100.

Badan Pemeriksa Keuangan Republik Indonesia. (2020). Webinar: Pertanggungjawaban dan Pemeriksaan Pengelolaan Keuangan Daerah dalam Masa Relaksasi Kebijakan Keuangan akibat Pandemi Covid-19. Jakarta.

Badan Pemeriksa Keuangan Republik Indonesia. (2020). Webinar: Strategi Audit Dana Bencana dan Peran Auditor Pemerintah. Jakarta.

Bastian, Indra. (2010). Akuntansi Sektor Publik Suatu Pengantar (Public Sector Accounting An Introduction). Erlangga. Jakarta.

CNN. Diakses pada Juli, 12, 2020, dari https://www.cnnindonesia.com/nasional/20200628162812-20-518359/jumlah-pasiensembuh-corona-ri-catat-rekor-tertinggi-hari-ini

Dan, P., Dana, P., Hasil, B., Umum, D. A., Dana, D. A. N., Daerah, I., Anggaran, T., \& Rangka, D. (2020). www.jdih.kemenkeu.go.id.

Faradiba, H., dkk. (2020). The Ideal Financial Audit Models for Private Sector Assistance against COVID- 19 Pandemic. International Journal of Research and Review, 7(4).

Hanoatubun, S. (2020). Dampak COVID-19 Terhadap Perekonomian Indonesia. Journal of Education, Psychology and Counseling, 2(1).

Hakim, L., Sunardi, N. (2017). Determinant of leverage and it's implication on company value of real estate and property sector listing in IDX period of 2011-2015. Man in India, 97(24), pp. 131-148

Indonesia (2020). Instruksi Presiden No.4 Tahun 2020 Tentang Refocussing Kegiatan, Realokasi Anggaran, serta PBJ dalam rangka Percepatan Penanganan Covid-19. Inpres No. 4 Tahun 2020.

Indonesia (2008). Keputusan Badan Pemeriksa Keuangan Republik Indonesia Tentang Petunjuk Pelaksanaan Pemeriksaan Keuangan. KBPK No. 4/K/I-XIII.2/5/2008.

Indonesia (2020). Keputusan Badan Pemeriksa Keuangan Republik Indonesia Tentang Petunjuk Teknis Pemeriksaan Keuangan Pada Masa Darurat. KBPK No. 4/K/IXIII.2/5/2020.

Indonesia (2020). Keputusan Menteri Kesehatan Republik Indonesia Nomor HK.01.07/MENKES/238/2020 Tentang Petunjuk Teknis Klaim Penggantian Biaya Perawatan Pasien Penyakit Infeksi Emerging Tertentu Bagi Rumah Sakit yang Menyelenggarakan Pelayanan Corona Virus Disease 2019 (COVID 19). Kep. Menkes No.HK.01.07/MENKES/238/2020.

Indonesia (2020). Keputusan Menteri Keuangan Republik Indonesia Nomor 6/KM.7/2020 Tentang Penyaluran Dana Alokasi Khusus Fisik Bidang Kesehatan dan Dana Bantuan Operasional Kesehatan Dalam Rangka Pencegahan dan/atau Penanganan Corona Virus Disease 2019 (COVID 19). Kep. Menkeu No. 6/KM.7/2020. 
Indonesia (2020). Peraturan Pemerintah Pengganti Undang-Undang No.1 Tahun 2020 Tentang Kebijakan Keuangan Negara dan Stabilitas Sistem Keuangan untuk Penanganan Pandemi Covid-19 dan/atau Dalam Rangka Menghadapi Ancaman Yang Membahayakan Perekonomian Nasional dan/atau Stabilitas Sistem Keuangan. Perppu No. 1 Tahun 2020. LN No.87 Tahun 2020, TLN No. 6485.

Indonesia (2006). Peraturan Presiden No. 8 Tahun 2006 Tentang Pelaporan Keuangan dan Kinerja Instansi Pemerintah. Perpres No. 8 Tahun 2006.

Indonesia (2018). Peraturan Presiden No.11 Tahun 2018 Tentang Pengadaan Barang/Jasa Pemerintah. Perpres No. 11 Tahun 2018. LN No. 33 Tahun 2018.

Indonesia (2004). Undang-Undang No.15 Tahun 2004 Tentang Pemeriksaan Pengelolaan dan Tanggung Jawab Keuangan Negara. UU No. 15 Tahun 2004. LN No. 66 Tahun 2004, TLN No. 4400.

Indonesia (2020). Surat Edaran Komisi Pemberantasan Korupsi Nomor 11 Tahun 2020 Tentang Penggunaan Data Terpadu Kesejahteraan Sosial (DTKS) dan data non-DTKS dalam pemberian Bantuan Sosial ke Masyarakat. SE No. 11 Tahun 2020.

Indonesia (2020). Surat Edaran Menteri Kesehatan Nomor HK.02.01/MENKES/295/2020 Tentang Klaim Penggantian Biaya Perawatan Pasien Penyakit Infeksi Emerging Tertentu Bagi Rumah Sakit yang Menyelenggarakan Pelayanan Corona Virus Disease 2019 (COVID-2019). SE No. HK.02.01/MENKES/295/2020.

Jensen, M.C. dan W.H. Meckling. (1976). Theory of the Firm: Managerial Behaviour, Agency Cost, and Ownership Structure. Journal of Financial Economics 3, hlm. 305-60.

Kadim, A., Sunardi, N., \& Husain, T. (2020). The modeling firm's value based on financial ratios, intellectual capital and dividend policy. Accounting, 6(5), 859-870.

Sunardi, N. (2019, January). Relevansi Struktur Kepemilikan Tentang Profitabilitas Dan Nilai Perusahaan (Studi pada Industri Manufaktur yang Terdaftar di Bursa Efek Indonesia Periode 2010-2017). In Proceedings (Vol. 1, No. 1).

Sunardi, N., Hamid, A. A., Lativa, A. K., \& Tulus, N. (2018). Determinant Of Cost Efficiency And It's Implications For Companies Performance Incorporated In The Lq. 45 Index Listing In Idx For The Period of 2011-2016. International Journal of Applied Business and Economic Research, 16(1).

Sunardi, N., \& Permana, R. D. I. (2019). Faktor-Faktor Yang Mempengaruhi Harga Saham Dan Dampaknya Pada Nilai Perusahaan (Studi Kasus pada Perusahaan Sub Sektor Pertambangan Minyak dan Gas Bumi yang Terdaftar di Bursa Efek Indonesia Tahun 2013-2017). JIMF (Jurnal IImiah Manajemen Forkamma), 2(2).

Setyaningrum, Dyah. (2012). Analisis Faktor-Faktor yang Mempengaruhi Kualitas Audit BPKRI. Simposium Nasional Akuntansi XV. Banjarmasin.

Sujai, M. (2012). Evaluasi Percepatan Penyerapan Anggaran Kementerian dan Lembaga. Jurnal IImu Administrasi, 9(1).

Zimmerman, Jerold L. (1977). The Municipal Accounting Maze: An Analysis of Political Incentives. Journal of Accounting Research, 15(107-144).

Jurnal SEKURITAS (Saham, Ekonomi, Keuangan dan Investasi ), Vol.4, No.1, September 2020....42 